\title{
LONG WAY FROM HOME
}

\section{EMMA LAROCQUE}

1994. Reprinted with permission from ARIEL: A Review of International English Literature. Vol.25:1.

\section{Long Way From Home}

I've walked these hallways

a long time now

hallways held up by

stale smoke

thoughts

I've walked these hallways

a long time now

hallways pallored by

ivory-coloured

thoughts

I've walked these hallways

for a long time now

hallways without windows

no way to feel the wind

no way to touch the earth

no way to see

I've walked these hallways

a long time now

every September closed doors

stand at attention

like soldiers

guarding fellow inmates

guarding footnotes 
guarding biases

as I walk by

I do my footnotes so well

nobody knows where I come from

hallways without sun

the ologists can't see

they count mainstreet

bodies behind bars

they put Ama's moosebones

behind glass

they tell savage stories

in anthropology Cree

My fellow inmates

they paste us prehistoric

standing in front of us

as if I am not there too

as if I wouldn't know

what they think they show

showing what they don't know

they don't know what they show

they take my Cree for their PhD's

like Le Bank

as my Bapa would say

they take our money for their pay

When I first came to these hallways

I was young and dreaming

to make a difference

thinking truth

With footnotes pen paper

chalk blackboard

I tried to put faces

behind cigar store glazes

I tried to put names

behind the stats

of us brown people 
us

us brown people

in jails

in offices

in graveyards

in livingrooms

but to them it was

just Native biases

I've walked these hallways

a long time now

hallways hallowed by

ivory-towered

bents

way too long now

hallways whitewashed with

committee meetings memos

promotion procedures

as fair as war

pitting brown against colonized brown

choosing pretend Indians

When I first came to these hallways

I was young and dreaming

to make a difference

but only time has passed

taking my Ama and Bapa

my Nhisis my Nokom

my blueberry hills

I've walked these hallways

a long time now

I wanna go home now

I'm tired of thinking for others

who don't wanna hear anyways

I wanna go home now

I want to see the evening stars 
get together for a dance

the northern light way

like Ama's red river jig

I want to see the sun rise

hot orange pink

like Bapa's daybreak fire

no one could see the morning come

as my Bapa

no one could scurry in the stars

as my Ama

I wanna go home now

but where is home now?

I do my footnotes so well

nobody knows where I come from

my relatives think

I've made it

they don't know

how long I've walked these hallways

my feet hurt

at 43

I wanna play hookey

but I can't

I have credit cards to pay

footnotes to colonize

My relatives think

I've made it

they don't know

who all owns me

they won't lend me money

from their UIC's

my relatives laugh.

Oh I did my footnotes so well

nobody knows where I come from

I've walked these hallways

with them a long time now 
and still they don't see

the earth gives eyes

injustice gives rage

now I'm standing here

prehistoric and all

pulling out their fenceposts of civilization

one by one

calling names in Cree

bringing down their mooneow hills

in English too

this is home now. 